\title{
Triplectides larvae in empty cases of Nectopsyche (Trichoptera, Leptoceridae) at Parque Estadual Intervales, São Paulo State, Brazil
}

\author{
Vera Lúcia Crisci-Bispo ${ }^{1}$, Pitágoras C. Bispo ${ }^{1} \&$ Cláudio G. Froehlich ${ }^{1}$
}

${ }^{1}$ Departamento de Biologia, Faculdade de Filosofia, Ciências e Letras de Ribeirão Preto, Universidade de São Paulo. 14040-901
Ribeirão Preto-SP, Brazil. E-mail: crisci@usp.br; pitbispo@usp.br; cgfroeh@usp.br.

\begin{abstract}
Resumo. Larvas de Triplectides em casas vazias de Nectopsyche (Trichoptera, Leptoceridae), no Parque Estadual Intervales, Estado de São Paulo, Brasil. A frequente ocorrência de larvas de Triplectides sp. em casas de Nectopsyche no Ribeirão Bocaina (Parque Estadual Intervales, São Paulo, Brasil) foi registrada. Acúmulos de folhas foram coletados de novembro de 1999 a junho de 2000 em corredeiras e remansos. Larvas de Triplectides sp. em casas de Nectopsyche foram encontradas principalmente em remansos.

Palavras-Chave. Abrigos larvais; Nectopsyche; Parque Estadual Intervales; Trichoptera; Triplectides.

Abstract. The frequent occurrence of Triplectides sp. larvae in cases of Nectopsyche Müller in Ribeirão Bocaina, Parque Estadual Intervales, São Paulo, Brazil is recorded. Leaf packs were collected from November 1999 to June 2000 in riffles and pools. Triplectides sp. larvae in cases of Nectopsyche were found mostly in pools.
\end{abstract}

Keywords. Larval cases; Nectopsyche; Parque Estadual Intervales; Trichoptera; Triplectides.

Trichoptera larvae produce silk with their labial glands. The silk is used to build retreats, nets for food uptake, and cases (Wiggins 1996; ANGrisano \& Korob 2001). Cases are built by the majority of Trichoptera families, a wide diversity of materials is used in case construction and the shapes are variable. The type of the case may be used to identify taxa to genus, but convergences occur and empty cases may be occupied by opportunistic larvae.

Larvae of the leptocerid genera Triplectides Kolenati, 1859 and Nectopsyche Müller, 1879 are easily recognized. In the first one, the metanotum has four sclerites and the tibiae of the hind legs are divided; in the second, the metanotum is membranous and the lateral tubercle of the first abdominal segment has a sclerotized bar and a circular roughened area (ANGRISANO \& KOROB 2001). Figures of the genera are found in Holzenthal $(1988,1995)$ and Wiggins (1996). Here the occupation of cases of Nectopsyche by larvae of Triplectides sp. is recorded.

The study site was Parque Estadual Intervales, São Paulo, Brazil. The park is located in the Serra de Paranapiacaba, inside the protection area of the Serra do Mar, and includes parts of the municipalities of Ribeirão Grande, Eldorado, Guapiara, Iporanga and Sete Barras. Situated between $24^{\circ} 12^{\prime}$ and $24^{\circ} 32^{\prime} \mathrm{S}$, and $48^{\circ} 03^{\prime}$ and $48^{\circ} 32 \mathrm{~W}$, it has an area of $417 \mathrm{~km}^{2}$ ( CAMPOS 2001). Collectings were done in Ribeirão Bocaina, a second order stream, at $24^{\circ} 16^{\prime} 21^{\prime \prime} \mathrm{S}$ and $48^{\circ} 27^{\prime} 16^{\prime \prime} \mathrm{W}$. Leaf packs in pools and riffles (10 sampling units each) were collected with a D-net from November 1999 through June 2000. Voucher material is deposited in the Museu de Zoologia, Universidade de São Paulo, São Paulo, Brazil (MZSP).

Two hundred and two Triplectides sp. and 954 Nectopsyche sp. larvae were collected. In pools, the numbers were 195 Triplectides $\mathbf{s p}$. and 16 Nectopsyche sp. larvae; in riffles, seven Triplectides $\mathbf{s p}$. and 938 Nectopsyche $\mathbf{s p}$. A high frequency of Triplectides sp. larvae were found in Nectopsyche larval cases: in pools, 173 (89\%) and in riffles, four (57\%).

Triplectides larvae do not build elaborate cases, generally occupying small hollowed out twig fragments or discarded cases of other caddisflies (FLINT et al. 1999). HolzentHAL (1988) mentions Flint's observation of the occurrence of Triplectides larvae in cases of Parasericostoma Schmid, 1957 in Chile and Grumicha Müller, 1879 (Trichoptera, Sericostomatidae) in Brazil. We also found three Triplectides sp. larvae in Grumicha cases.

We observed that Triplectides sp. larvae occur primarily in pools while those of Nectopsyche sp. are riffle-dwelling. The high frequency of Triplectides sp. larvae in cases of Nectopsyche was observed in leaf accumulations in pools, indicating that the discarded cases of Nectopsyche larvae in riffles are carried to pools, where they are utilized by the resident Triplectides sp. larvae. Corroborating Flint (apud Holzenthal 1988), our results indicate that Triplectides larvae are opportunists, occupying empty cases of other caddisflies, in addition to hollow twigs. 
Acknowlegements. We thank CAPES, FAPESP and CNPq for fellowships granted to the authors and Museu de Zoologia, Universidade de São Paulo for its support. This work was supported by the Fundação de Amparo à Pesquisa do Estado de São Paulo (FAPESP) within the BIOTA/FAPESP (www.biota.org.br).

\section{REFERENCES}

Angrisano, E. B. \& P. G. Korob 2001. Trichoptera, p. 55-92. In: H. R. Fernández \& E. Domínguez (Eds.). Guía para la Determinación de los Artrópodos Bentónicos Sudamericanos. Tucumán, Universidad Nacional de Tucumán.

CAmpos, F. P. 2001. Parque Estadual Intervales e o serviço de áreas naturais protegidas, p. 11-19. In: C. LeONEL (ed.). Intervales: Fundação Para Conservação e a Produção Florestal do Estado de São Paulo. São Paulo, Secretaria de Estado do Meio Ambiente de São Paulo, 240 p.

Flint, O. S. JR.; R. W. Holzenthal \& S. C. Harris 1999. Catalog of the Neotropical Caddisflies (Insecta: Trichoptera). Columbus, Ohio Biological Survey, iii +239 p.

Holzenthal, R. W. 1988. Systematics of Neotropical Triplectides (Trichoptera: Leptoceridae). Annals of the Entomological Society of America 81(2): 187-208.

Holzenthal, R. W. 1995. The caddisfly genus Nectopsyche: New gemma group species from Costa Rica and Neotropics (Trichoptera: Leptoceridae). Journal of the American Benthological Society 14(1): 61-83.

Wiggins, G. B. 1996. Larvae of the North American Caddisfly Genera (Trichoptera). $2^{\text {nd }}$ ed. Toronto, University of Toronto Press, xii +457 p.

Received 11.III.2003; accepted 30.XI.2003 